\title{
The Drivers of Child Mortality During the 2012-2016 Drought in La Guajira, Colombia
}

\author{
Diana Contreras ${ }^{1,2} \cdot$ Alex Voets $^{3} \cdot$ Jana Junghardt $^{4} \cdot$ Srirama Bhamidipati $^{5}$. \\ Sandra Contreras ${ }^{6}$
}

Published online: 19 February 2020

(C) The Author(s) 2020

\begin{abstract}
During the 2012-2016 drought in La Guajira, Colombia, child mortality rates rose to 23.4 out of 1000 . Most of these children belonged to the Wayuu indigenous community, the largest and one of the most vulnerable in Colombia. At the municipal level, this study found a significant positive correlation between the average child mortality rate and households with a monthly income of less than USD 100, the number of people without access to health insurance, being part of the indigenous population, being illiterate, lacking sewage systems, living in rural areas, and large households with members younger than 5 years old and older than 65 years old. No correlation was found with households without access to a water source. The stepwise regression analysis showed that households with a monthly income of less than USD 100, no members older than 65 years old, but several children younger than 5 years old, account for $90.4 \%$ of the child mortality rate. This study concludes that, if inhabitants had had better incomes or assets, as well as an adequate infrastructure,
\end{abstract}

Diana Contreras

diana.contreras@cigiden.cl; diana.contreras-

mojica@newcastle.ac.uk

1 Research Center for Integrated Disaster Risk Management (CIGIDEN), Pontifical Catholic University of Chile, 7820436 Macul, Santiago, Chile

2 School of Engineering, Newcastle University, Newcastle upon Tyne, Northumbria NE1 7RU, UK

3 Caritas Switzerland, Bogotá, D.C. 110231, Colombia

4 Caritas Switzerland, 6002 Luzern Lucerna, Switzerland

5 Faculty of Technology, Policy and Management, Delft University of Technology, 2628 BX Delft, The Netherlands

6 Communication and Language, Pontifical Xavierian University, Bogotá, D.C. 110231, Colombia they could have faced the drought without the observed increase in child mortality.

Keywords Child mortality · Climate change $\cdot$ Drought $\cdot$ Socioeconomic vulnerability $\cdot$ Water management . Wауии indigenous community

\section{Introduction}

Poor people in Latin American countries such as Colombia, Guyana, and Honduras are overexposed to droughts and high temperatures. Droughts are likely to become more common and severe in places where they already occur (Hallegatte et al. 2016). Between 2012 and 2016, a long drought took place in La Guajira, Colombia due to El Niño phenomenon. The monthly average precipitation in the high Guajira dropped from $30 \mathrm{~mm}$ in 2012 to as little as $5 \mathrm{~mm}$ in 2015 (Bonet-Morón and Hahn-De-Castro 2017). The water scarcity reduced crop production and led to food insecurity within the department (Contreras et al. 2016), stopping the decreasing tendency of child mortality in $\mathrm{La}$ Guajira and even increasing this tendency again in some of the municipalities of the department (Avilés 2019).

Colombia is divided into 32 departments, one of which is La Guajira in the far northeast, between the Caribbean Sea and Venezuela. The department with a total area of $20,848 \mathrm{~km}^{2}$ is divided into 15 municipalities (Fig. 1), with Riohacha on the coast as the capital. The department is located in three natural subregions: high, middle, and low Guajira, as shown in Fig. 2. The high Guajira is a semidesert area, where the vegetation is scarce. The middle Guajira consists of semi-desert zones with tropical dry forest but also with agricultural potential. Nevertheless, areas with the best conditions for agriculture are in the low 


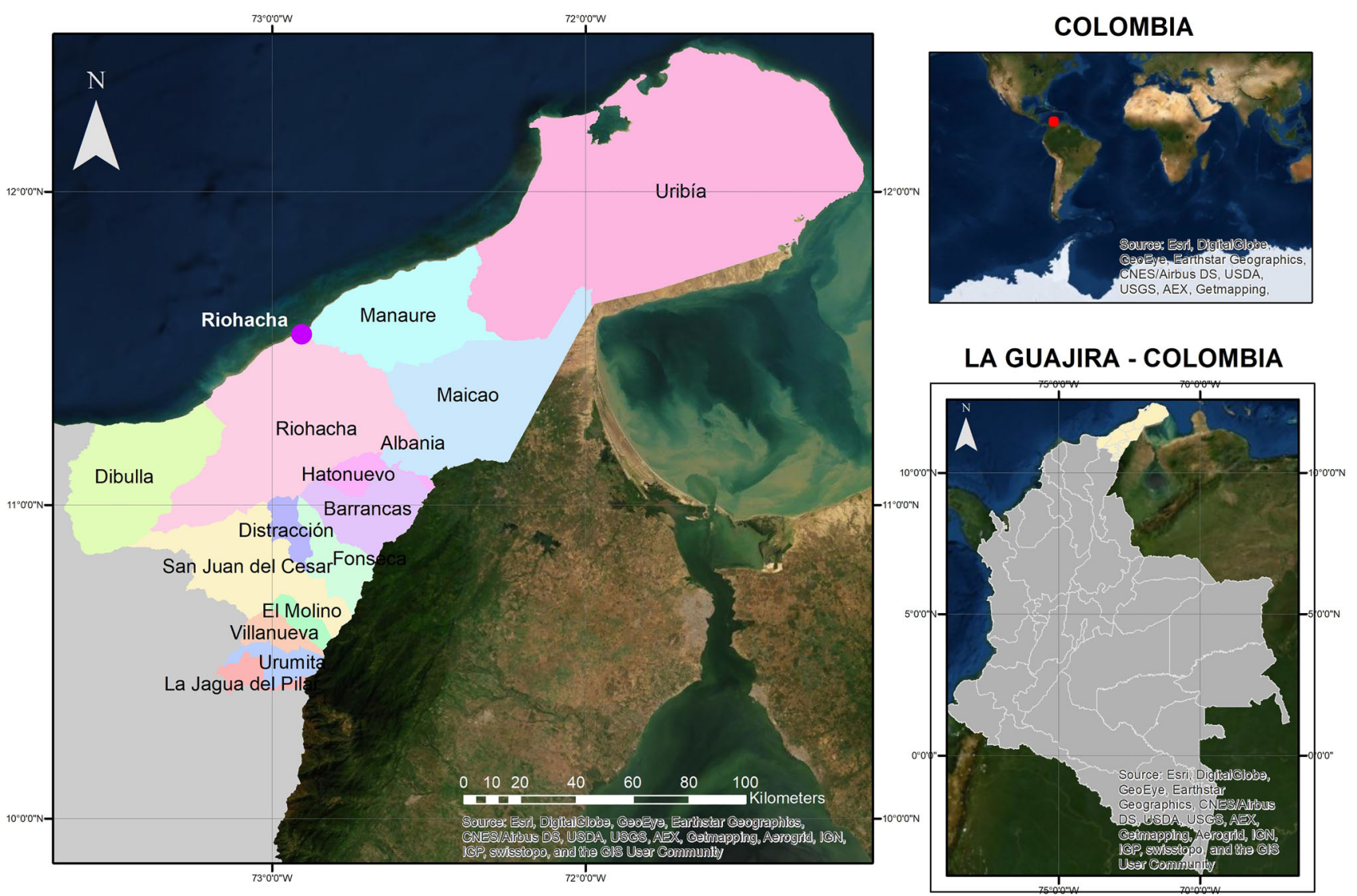

Fig. 1 Location and municipalities of La Guajira Department, Colombia

Guajira due to its closeness to Rancheria and El Cesar Rivers (CCG 2017).

The precipitation in La Guajira is less than $500 \mathrm{~mm}$ per year, and temperatures vary between 35 and $42{ }^{\circ} \mathrm{C}$ throughout the year (IDEAM et al. 2017). Based on the 2005 population census projections (2005-2020), about $44.9 \%$ (454,804 inhabitants) of the total population in $\mathrm{La}$ Guajira (1,012,926 inhabitants) are indigenous people from four communities: Wayuu, Kogi (Kaggaba), Wiwa (Arzario), and Arhuaco (Ijka) (CCG 2017). The Wayuu are the largest indigenous community in La Guajira and in Colombia, and one of the most vulnerable. They account for $20 \%$ (381,123 Wауии population) of the total indigenous population in Colombia $(1,905,617$ indigenous population). The Wayuu's ancestral land includes the high and middle Guajira and the northwestern part of Venezuela (Fig. 3); therefore, they have both the Colombian and Venezuelan citizenships and free transit between the two countries.

The people of the Wауии indigenous community can largely be divided into two groups based on their activities: apaalanchi (fishers) and arumewi (shepherds). However, during the dry season they migrate to Riohacha to work in the construction industry or any low-skill jobs, to look for grass for their cattle in the low Guajira or to secure jobs in the extraction of salt (Hostein 2012) in Manaure still in the high Guajira. During the eighteenth and the nineteenth centuries, members of the Wауии indigenous community already migrated to Venezuela during the dry season to work on the cocoa, coffee, and indigo plantations. This migration further intensified in the twentieth century with the demand for a labor force to work in various oil facilities (Hostein 2012). Smuggling was one of the other economic activities since the Spanish conquerors' arrival in this region, and it remained prevalent until the 1970s when the traffic of marihuana became an alternative source of income for the region until the beginning of the 1980s (Contreras et al. 2016). Due to its isolated geographic position, La Guajira is a favorable territory for all kinds of illicit trafficking, including drug running. The latter has become an essential source of income for the Wayuu population (Hostein 2012), but also a source of conflict in the department.

Factors such as water scarcity, high temperatures, and soil salinization contribute to a desertification process and together with the dredging of the sandbank of Lake Maracaibo make the exploitation of marine resources difficult, making it challenging to find sources of livelihood in 


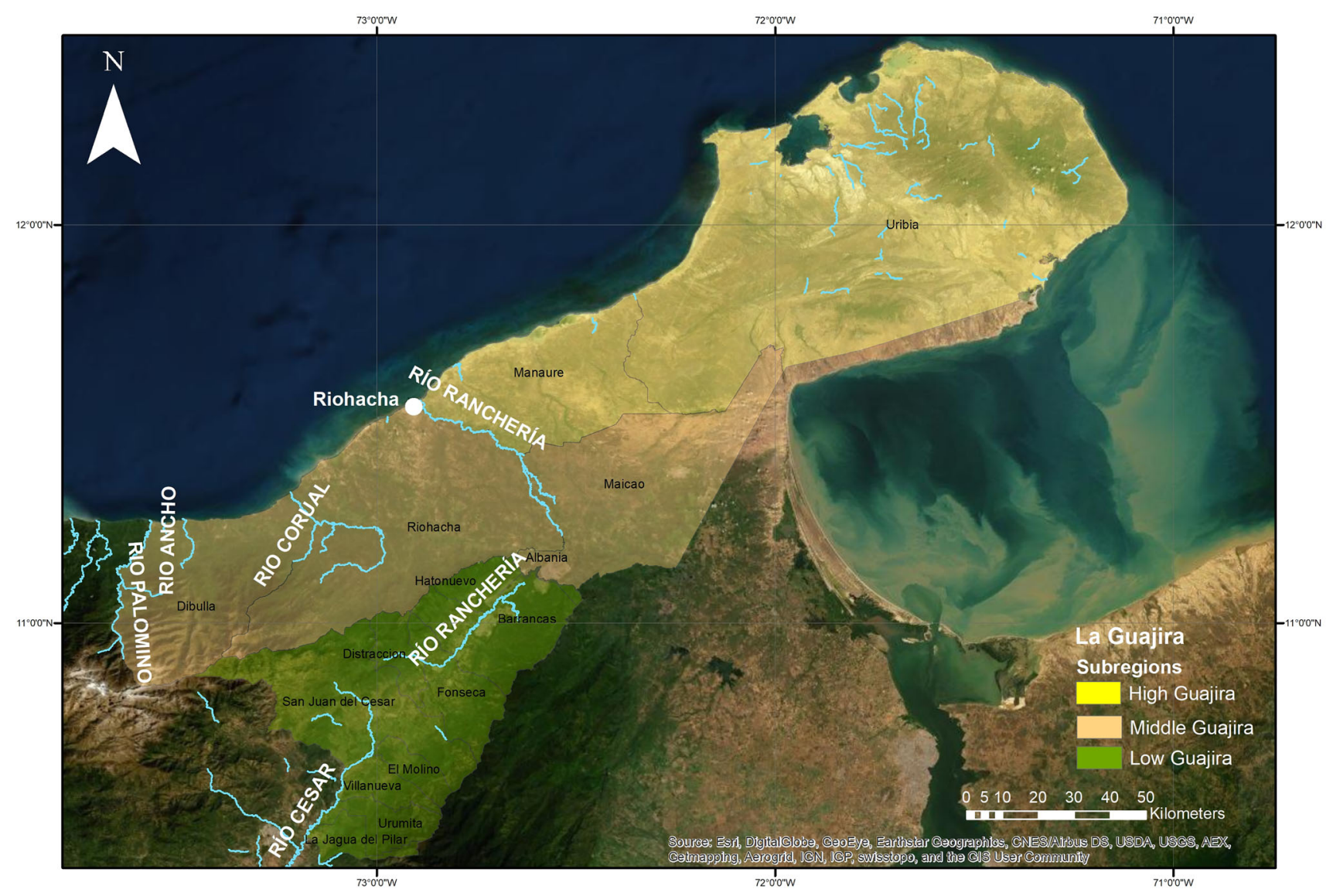

Fig. 2 Natural subregions and rivers in La Guajira Department, Colombia

this region (Hostein 2012). The members of the Wayuu indigenous community are known for their coping capacity and adaptation strategies to survive in the desert (Hostein 2012) with their herds of goats and rams (Castro-Aniyar 2016), subsistence crops, crops with medicinal properties to sell, and weaving bags and hammocks. Nevertheless, famine among Wауии children was already recorded as early as 1776 by members of the Spanish army (Guerra 2016), in 1920 by the Swedish researcher Gustaf Bolinder and 1973 by the French ethnologist Michel Perrin (BonetMorón and Hahn-De-Castro 2017). More recently, between 2012 and 2016, a long drought took place in La Guajira due to an El Niño event. The monthly average precipitation in the high Guajira dropped from $30 \mathrm{~mm}$ in 2012 to as little as $5 \mathrm{~mm}$ in 2015 (Bonet-Morón and Hahn-De-Castro 2017). In addition to the drought, the water scarcity in La Guajira is caused by controversial water management. The water supply system covers $87 \%$ of the urban areas, but only $22 \%$ of the rural areas of the department, while in the rest of Colombia, the water supply system covers $97 \%$ and $73 \%$, respectively (CCG 2017). The El Cercado dam was built on the main river in the department. The dam was completed in 2010 with the purpose to mitigate the effects of the cyclical droughts in La Guajira, to supply water to the aqueducts of nine municipalities, and to provide irrigation for agriculture. But the pipes to conduct the water lead nowhere. The flow barely makes it past the rice crops, cattle ranches, and El Cerrejon (Avilés 2019), the tenthlargest open-pit coal mine (by reserve) in the world (Mining Technology 2013), all of which tap into the river below the dam. By the time the flow of the river reaches the middle Guajira (Contreras 2019), it is reduced to almost a trickle (Guardian 2015; Contreras et al. 2016). While the Wayиu indigenous community does not have access to the basic requirement of 21 of water per person per day for cleaning and for preparing food (Guillén 2016), the coal mine uses 17 million liters per day (Correa 2015; Avilés 2019). Additionally, a $3.6 \mathrm{~km}$ section of the Arroyo Bruno (Bruno Stream), a tributary of the Rancheria River, was diverted into a new channel in 2016 to extract 35 million tons of coal located under it (Silva 2016).

Our hypothesis was that the high child mortality rate between 2012 and 2016 in La Guajira was triggered by the lack of access to water sources due to the drought caused by the El Niño event. The child mortality rates in La Guajira rose to 23.4 per 1000 in this period (CCG 2017).

The next section reviews the literature on the concept and the indices to measure drought, water scarcity, and 


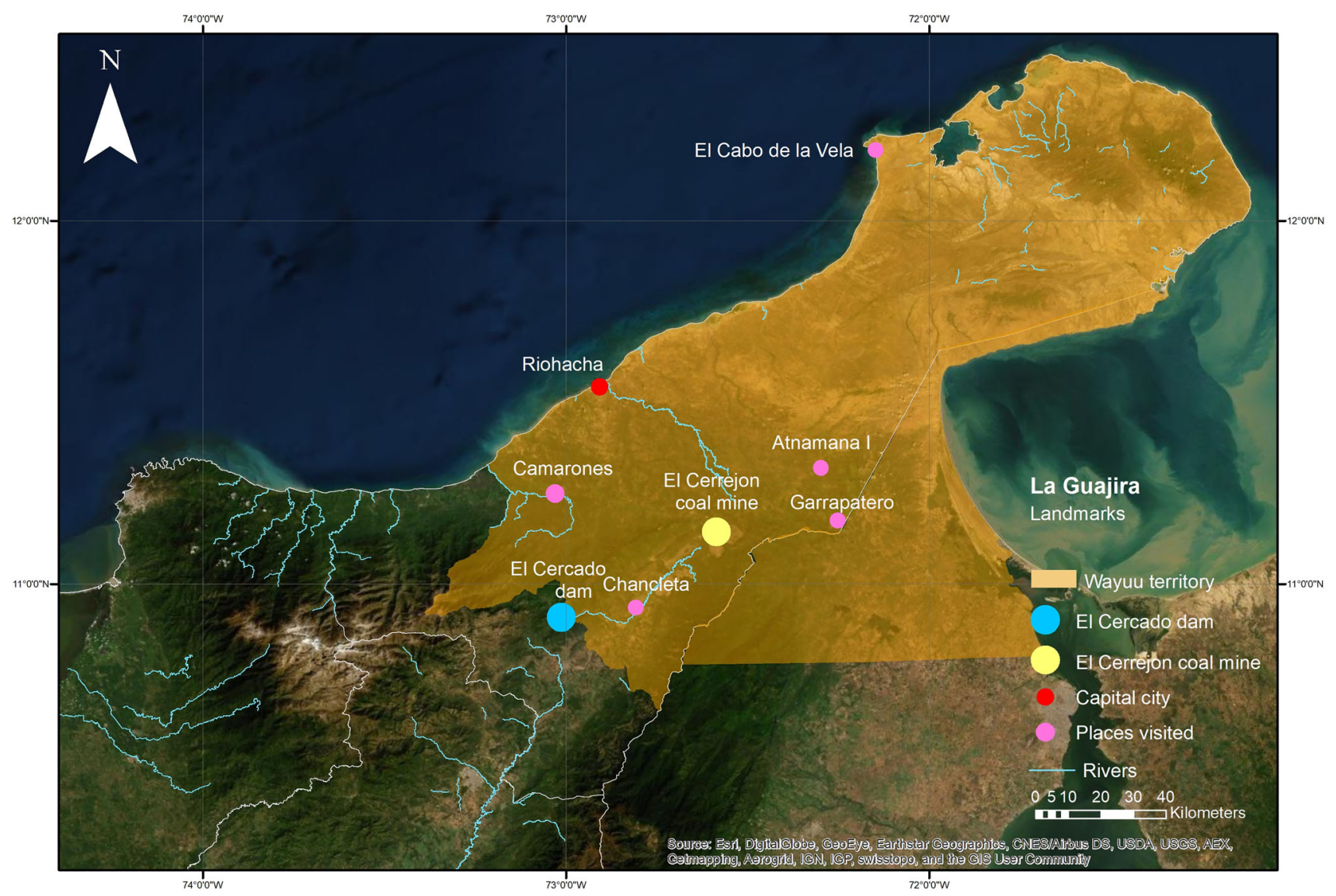

Fig. 3 Data collection areas and landmarks in La Guajira

food insecurity in the world, Latin America, and the Caribbean. The third section describes the methodology of the study, including data collection and statistical analysis. The fourth and fifth sections describe and discuss the results, respectively. Section sixth addresses the conclusion of the research and section seventh the recommendations.

\section{Literature Review}

Between 1994 and 2013, more than one billion people were affected by drought worldwide (UNISDR and CRED 2015). There are two common definitions of drought in the literature: a conceptual definition and an operational one (Pedro-Monzonís et al. 2015). The conceptual definition describes droughts as a natural hazard that results from a reduction in precipitation, which turns into an insufficient amount of water to meet the needs of human activities or ecosystems (Estrela and Vargas 2012). The operational definition focuses on identifying the beginning, end, and severity of droughts. According to the conceptual definition, there are four kinds of droughts: meteorological, agricultural, hydrological, and socioeconomic (Mishra and Singh 2010). Delbiso et al. (2017), describe drought as a slow-onset natural cyclical event that worsens gradually, and, if not addressed properly, ends in destitution, starvation, and death. The continued shortage of precipitation is defined as a meteorological drought. It usually triggers other kinds of droughts and affects large areas. Agricultural drought is a moisture deficit in the root area that fails to meet the needs of crops, while hydrological drought is considered a period of low flows and below-normal flows in watercourses, lakes, and low groundwater levels. Socioeconomic drought is linked to the effect of water scarcity on people and economic activity, thus causing social and environmental impacts (Mishra and Singh 2010). There are several indices to quantify, monitor, and analyze drought, such as the standardized precipitation evapotranspiration index (SPEI), the standardized precipitation index, and the Palmer drought severity index (Delbiso et al. 2017).

Early warning systems (EWS) are defined as the timely provision of information through recognized institutions that allow individuals exposed to a drought hazard to act and reduce its impact and prepare for effective responses (Wilhite and Svoboda 2000). An early warning system is one of the behavioral anticipated climate change adaptation (CCA) options to help farmers make informed decisions for 
harvesting crops. Early warning systems enable farmers to predict droughts, take preventive measures, and adopt coping strategies (FAO 2013). Nhamo et al. (2019) assessed the spatiotemporal changes in water resources over time in southern Africa to measure the changes in aridity and rainfall patterns to justify the need for an EWS.

Water availability depends on precipitation, seasonal cycles, snow peaks, and evaporation rates. Local climate and the evolution of droughts will vary with location. Water scarcity is due not only to lack of rain, but also due to human actions (Jaeger et al. 2013). The scarcity of water in a region must be understood in the spatial and temporal context. Availability of water resources is defined as the ability to obtain water to fulfill basic needs, taking into account the time and distance to collect the water, rights to access, and costs (Desalegn et al. 2006). Water scarcity is a general problem in arid and semiarid regions such as the Yellow, Jordan, Murray-Darling, Colorado, and the Rio Grande rivers. The impacts of climate change will exacerbate water scarcity and make droughts more frequent (Kahil et al. 2016).

Allouche (2011) emphasizes that the stress on water and food systems can be induced by war or conflict, economic crisis, or climate change. About $70 \%$ of global freshwater is used for agricultural purposes. International commissions have recommended increasing investment in irrigated agriculture in Sub-Saharan Africa to improve food production, livelihoods, and the resilience of communities to climate change. In rural communities in Namibia, for example, user associations administer and set the rules for water management practices. The rules regulate boundaries and define contributions from members and outsiders. Research by Schnegg and Bollig (2016) demonstrated that during the 2012-2014 meteorological drought in Namibia, kinship and reciprocity took priority over formal agreements.

Undernourishment in Latin America and the Caribbean has increased in recent years. In 2016, around 42.5 million people $(6.5 \%)$ from a total of $653,962,331$ inhabitants did not have enough food to cover their daily calorie intake needs. These official figures represent an increase of $6 \%$ compared to the previous year (FAO and PAHO 2017). The increase can be explained by the unfavorable economic conditions faced by Latin America and the Caribbean in the last few years (FAO and PAHO 2017). The country with the greatest proportion of undernourishment in the region is Haiti, where $47 \%$ of the population is unable to cover its minimum dietary requirements. Other countries that show recent increases in the prevalence of undernourishment in Latin America and the Caribbean are Argentina, Ecuador, El Salvador, Grenada, Peru, and Venezuela. The most significant increase has been observed in Venezuela (FAO and PAHO 2017).
Nevertheless, organizations such as the Food and Agriculture Organization of the United Nations (FAO) and the Pan American Health Organization (PAHO) (2017) state that the food production of the region can cover the food needs of its population. Raleigh and Urdal (2007) indicated that climate change will influence the food-producing capacity in many areas of the world. They consider that resource scarcity is the consequence of the interaction of three factors: population growth, resource degradation, and the unfair distribution of resources among individuals and groups. Developing countries are more sensitive to resource scarcity.

Food security is considered to exist when everyone has access to sufficient, safe, and nutritious food at all times to maintain an active and healthy life (Cook 2002; ColemanJensen et al. 2013); this is a suitable environment in which to raise a child. Food security includes availability, accessibility (Poblacion et al. 2014), utilization, and stability of food for a healthy and active life (FAO et al. 2015). Healthy and affordable food must be on the market (Poblacion et al. 2016). The Intergovernmental Panel on Climate Change (IPCC) classifies areas with acute food insecurity into five phases: minimal, stressed, crisis, emergency, and famine (FAO/FSNAU 2006). Food insecurity (FI) is defined as the limited or uncertain access to nutritious food or to a diet sufficient in the quantity necessary for productive and healthy life (Pérez-Escamilla and Segall-Corrêa 2008; FAO 2012) in socially acceptable ways due to financial constraints (Pérez-Escamilla and Segall-Corrêa 2008). Food is important to maintain the function of body systems, especially in children (Poblacion et al. 2016).

Per capita or household income is an indicator of financial resources to purchase food and other goods and services. Variables such as type of water system, sewage system connection, and construction materials indicate housing quality, which is also related to the affordability of food at the household level (Poblacion et al. 2014). Household FI affects children's nutritional status by compromising the quality and quantity of dietary intake, producing undernutrition, and affecting parents, who do not have enough energy to provide care, prevent illness, and develop stimulation; this can also lead to depression (Weinreb et al. 2002; Hadley et al. 2008; Pérez-Escamilla et al. 2009; Poblacion et al. 2016) and stress (Fischer et al. 2014; Weigel et al. 2016). Food-insecure households consume less nutrient-dense foods due to lack of financial resources, increasing their risk of undernutrition and hospitalization (Perez-Escamilla et al. 2012). Improving the income of food-insecure households is essential to increase the consumption of vegetables, fruits, and meat (Bortolini et al. 2012). Living in a food-insecure household hinders human and socioeconomic development and contributes to 
the cycle of underdevelopment and malnutrition (Poblacion et al. 2016).

Food insecurity is prevalent in many low- and middleincome Latin American countries (Ribera 2012; Rodriguez et al. 2016; Smith et al. 2017; Sperandio et al. 2018; Espinosa-Cristia et al. 2019; de Sousa et al. 2019). One of the indicators to benchmark the severity of a crisis is the official child mortality rate, which also represents the general health of the population in a country (Working Group for Mortality Estimation in Emergencies 2007). The health impacts of drought are long-lasting and complex. Drought is linked to high mortality due to health problems related to undernutrition, micronutrient deficiency, and food- and water-borne diseases. Drought also aggravates chronic diseases, decreases crop and livestock production, contributes to the inflation of food prices, and leads to migration (Reuveny 2007; Jülich 2011). Poverty, deficient health infrastructure, and poor sanitation make the impacts of drought even worse (Stanke et al. 2013; Ebi and Bowen 2016). Limited household resources make children vulnerable to difficult health outcomes (Cook et al. 2004).

\section{Methodology}

The methodology section is divided into two subsections: data collection and data analysis. The data collection is from primary and secondary sources at the municipal level. The data analysis subsection explains the method of the socioeconomic vulnerability assessment and addresses the statistical analysis: correlation and regression.

\subsection{Data Collection}

Primary and secondary data were collected for the region of La Guajira. The primary data were collected in fieldwork through interviews (14), meetings (12), and workshops (3) (Contreras 2019). Between January 2017 and September 2018, 14 interviews with community members including social leaders, fishers, farmers, Wауии indigenous, colombians who returned from Venezuela, and people relocated due to the mine activities took place in the city of Riohacha and the townships of Atnamana-I, Chancleta, Camarones, and Garrapateros. The location of these places is plotted in Fig. 3. We visited Camarones because we were aware of the coping capacities and adaptation strategies of the fishers living there. Atnama I, Chancleta, and Garrapateros were visited following the suggestions of the nongovernmental organization (NGO) named Peace's Fabrics working in the case study area. In Atnamama I we could observe the problems of the farmers with the drought and their adaptation strategies. In the case of Chancleta, we noted the social uprooting due to the forced relocation caused by the mine activities (Avilés 2019). Garrapatero was visited to observe the resettlement of Venezuelan immigrants in a nature reserve that receives monetary compensation due to its environmental services. Additionally, 12 meetings were held with representatives of governmental institutions such as National Natural Parks and Unit of Risk due to Disaster Management (UNGRD for its acronym in Spanish), NGOs such as Diocese of Riohacha, Action Against Hunger (ACH), Food and Agriculture Organization of the United Nations (FAO), World Food Program (WFP)/PMA, Peace's Fabrics, Malteser International, and United Nations Office for the Coordination of Humanitarian Affairs (OCHA), and National Department of Planning (DNP for its acronym in Spanish). Three workshops also took place: two with community groups, the first workshop took place in Camarones and the second one in Garrapatero where the participatory assessment of climate and disaster risks methodology (PACDR) was applied by Diaz and Rubiano (2018). The third workshop took place in Riohacha with representatives of NGOs working in the case study area, governmental institutions, and the University of La Guajira to present the results of the assessment of climate change evaluation strategies in La Guajira, the application of the PACDR (Keller and Künzler 2014) methodology in Camarones and Garrapatero, and to design an action plan with the participants. Most of the activities were conducted within the framework of the project sponsored by the Swiss NGO Disaster Risk Reduction (DRR) platform and undertaken jointly with Caritas Switzerland $(\mathrm{CACH})$ to assess the impact of climate change in La Guajira, Colombia and opportunities for adaptation.

The primary data are qualitative in nature and were collected from a combination of unstructured and semistructured interviews recorded in audio and video. The interviews were focused on assessing the socioeconomic vulnerability conditions, and the existing coping and adaptation strategies of the inhabitants in La Guajira in the face of the challenges imposed by the impact of increased drought on the region.

The secondary data comprise the child mortality rates at the municipal level for the period from 2012 to 2016 published by the National Department of Statistics of Colombia (DANE 2017). Table 1 and Fig. 2 show the child mortality rates in La Guajira for under 1 year out of 1000 live births. The highest child mortality rates are observed in the municipalities of Uribia and Maicao.

The selected socioeconomic variables by municipality were identified from the interviews, meetings, and workshops involving the attendants of the workshops in Camarones and Garrapatero, the officials from governmental institutions, NGOs, and the University of La Guajira. Table 2 and Fig. 3 show a summary of the selected 
Table 1 Child mortality rates by municipality in La Guajira, Colombia. Source DANE (2017)

\begin{tabular}{llllllllllll}
\hline Number & Municipality & 2008 & 2009 & 2010 & 2011 & 2012 & 2013 & 2014 & 2015 & 2016 & Average \\
\hline 1 & Riohacha & 24.0 & 23.0 & 21.9 & 21.3 & 28.5 & 28.5 & 26.6 & 24.1 & 25.6 & 26.7 \\
2 & Albania & 31.9 & 31.9 & 31.9 & 31.7 & 26.8 & 24.1 & 24.1 & 23.9 & 24.1 & 24.6 \\
3 & Barrancas & 28.8 & 28.1 & 27.3 & 26.8 & 23 & 23 & 22.4 & 20.2 & 19.2 & 21.6 \\
4 & Dibulla & 28.1 & 26.8 & 25.5 & 25.5 & 18.3 & 16.5 & 15.1 & 15.1 & 14.7 & 15.9 \\
5 & Distracción & 24.5 & 23.4 & 22.2 & 20.4 & 25.1 & 22.6 & 21.8 & 21.8 & 21.9 & 22.6 \\
6 & El Molino & 28.7 & 27.5 & 26.3 & 25.1 & 17.7 & 15.9 & 16.9 & 17.7 & 17.3 & 17.1 \\
7 & Fonseca & 20.6 & 19.7 & 18.7 & 17.7 & 25.5 & 23 & 24.5 & 24.4 & 24.8 & 24.4 \\
8 & Hatonuevo & 29.2 & 27.9 & 26.5 & 25.5 & 19.1 & 17.2 & 17.2 & 18.4 & 17.9 & 18.0 \\
9 & La Jagua del Pilar & 21.0 & 20.1 & 19.1 & 19.1 & 26.1 & 23.5 & 22.7 & 21.8 & 22.2 & 23.3 \\
10 & Maicao & 30.1 & 29.6 & 29.0 & 29.0 & 48.8 & 48.8 & 47.7 & 49.6 & 47.9 & 48.6 \\
11 & Manaure & 54.4 & 54.4 & 54.4 & 54.3 & 19.1 & 18.8 & 18.5 & 19.2 & 18.9 & 18.9 \\
12 & San Juan del Cesar & 19.9 & 19.3 & 18.6 & 17.2 & 17.2 & 15.5 & 15.9 & 15 & 15.2 & 15.8 \\
13 & Uribia & 53.8 & 53.8 & 53.8 & 53.8 & 53.8 & 48.4 & 45.4 & 48.9 & 48.5 & 49.0 \\
14 & Urumita & 14.8 & 14.1 & 13.5 & 12.1 & 12.1 & 11.3 & 11.4 & 10.1 & 10.9 & 11.2 \\
15 & Villanueva & 17.0 & 16.2 & 15.5 & 13.9 & 13.9 & 12.5 & 13.7 & 14.1 & 13.7 & 13.6 \\
\hline
\end{tabular}

Deaths of children under 1 year out of 1000 live births, 2012-2016

variables by municipality in La Guajira and the level of socioeconomic vulnerability in La Guajira, respectively.

\subsection{Data Analysis}

\subsubsection{Socioeconomic Vulnerability Assessment}

We normalized the values of the variables to estimate the level of socioeconomic vulnerability per municipality using Eq. 1. Later the normalized values of these socioeconomic variables were integrated summing them using equal weight. The total of this sum was also normalized using again Eq. 1 and the outcoming values were classified into five nominal categories: very low, low, medium, high, and very high.

$Z_{i}=\frac{x_{i}-\min (x)}{\max (x)-\min (x)}$

where $Z_{i}$ is the normalized value, $x_{i}$ is the index of the variable, $x$ is the raw value of the variable

\subsubsection{Correlation Analysis}

Pearson's correlation was used in this study to measure the relationship between the child mortality rate at the municipal level for the period 2012-2016 and the socioeconomic indicators presented in Table 2. According to the literature review and the fieldwork observations, these variables can be associated with child mortality during the drought.

\subsubsection{Regression Analysis}

Since correlation only suggests the strength of a relationship and not the causality between indicators, it is still necessary to perform a regression analysis to test the predictive power of the indicators chosen. A stepwise regression analysis considered the average child mortality rate at the municipal level between 2012 and 2016 as the dependent variable, and the socioeconomic variables were used to remove the weakest correlated variables and identify those that best explained the distribution, avoiding collinearity between the independent variables (Fig. 4).

\section{Results}

This section is divided into three subsections: socioeconomic vulnerability assessment, correlation analysis, and regression analysis.

\subsection{Socioeconomic Vulnerability Assessment}

The result of the socioeconomic vulnerability assessment shows the highest level of vulnerability in the north and middle of the department, while the lowest levels of vulnerability are observed in the south (Fig. 5).

\subsection{Correlation Analysis}

Between 2012 and 2016, at the municipal level, a statistically significant positive correlation can be observed in La 


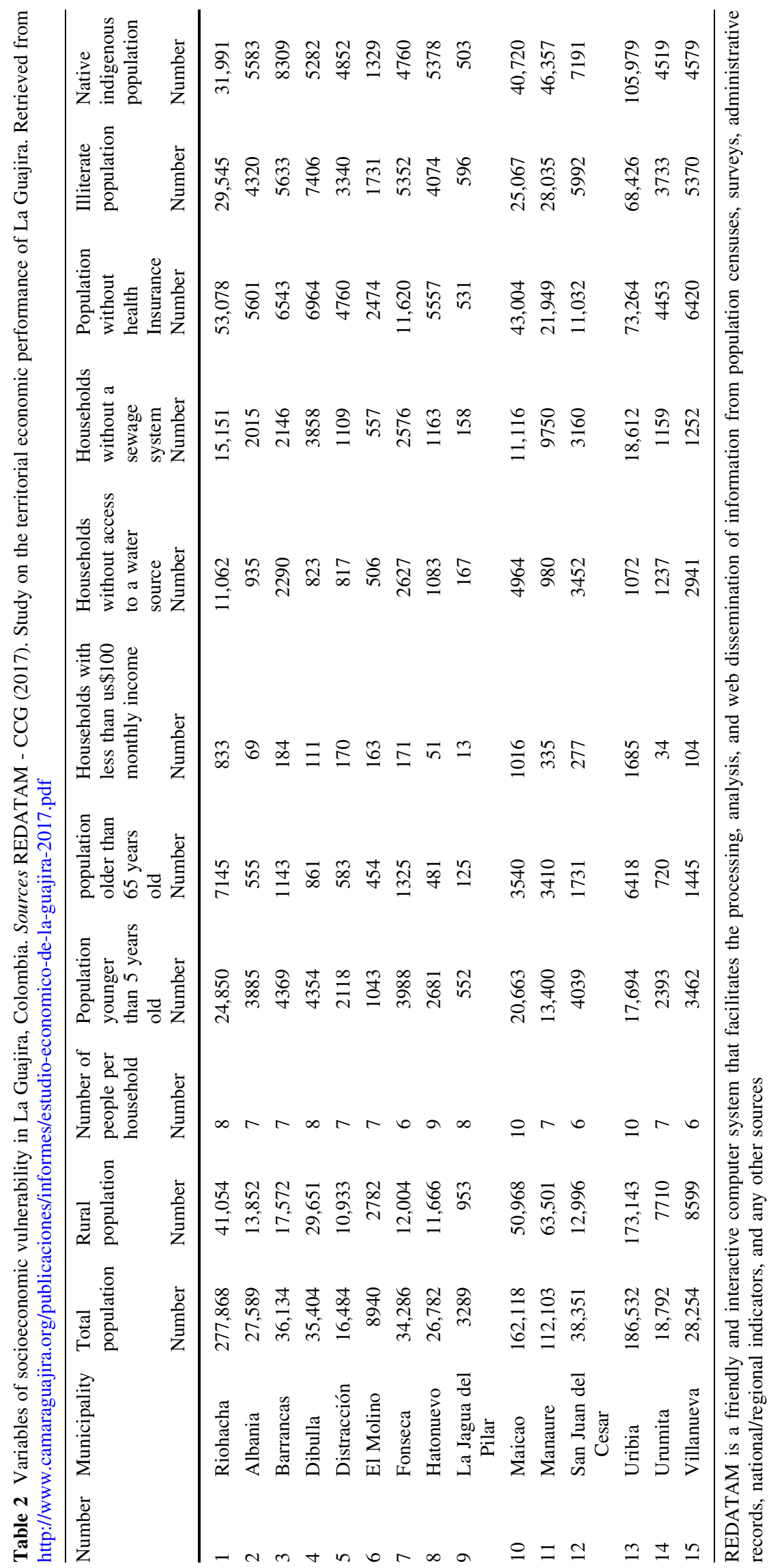




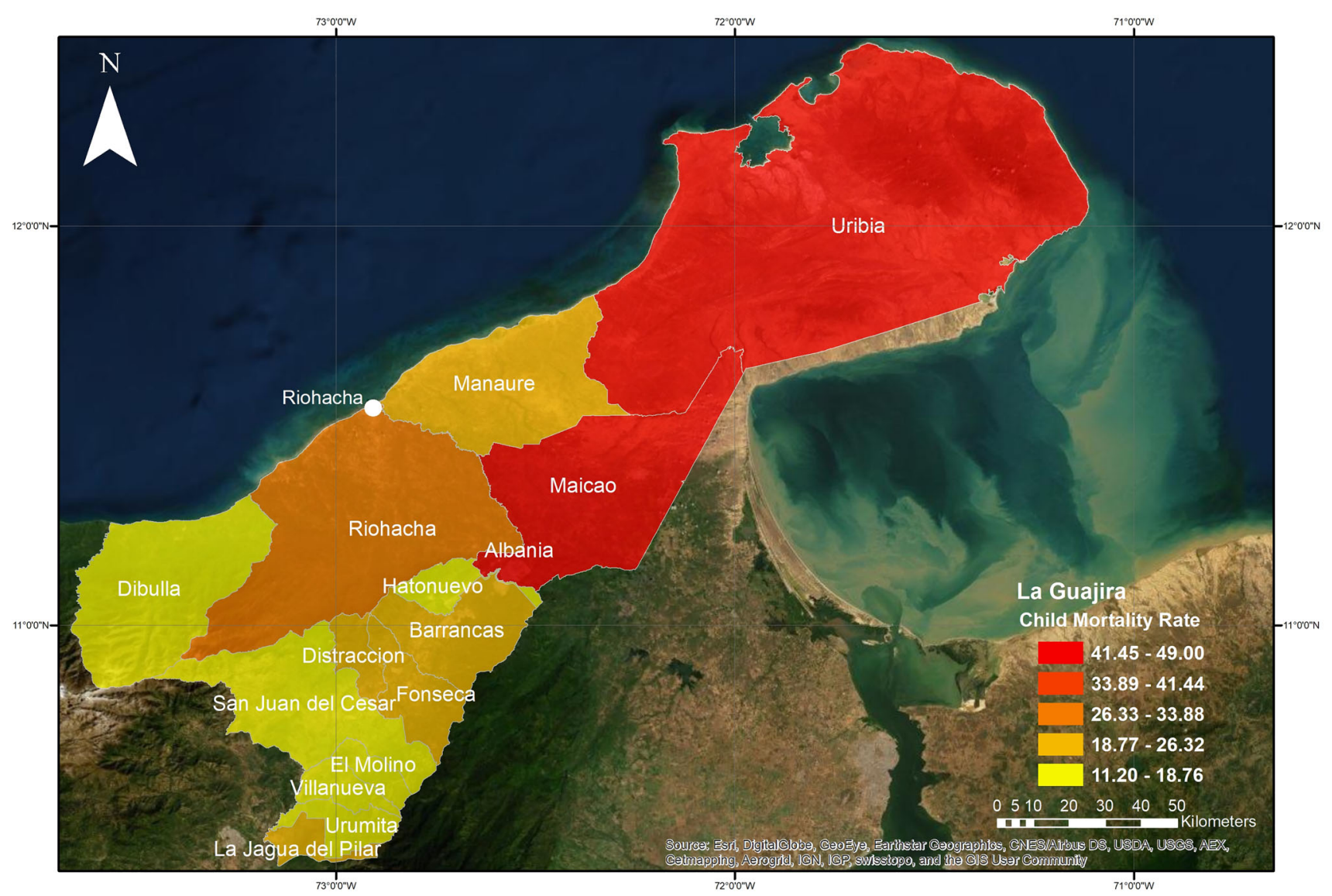

Fig. 4 Five year average (2012-2016) child mortality rates by municipality in La Guajira, Colombia

Guajira between the average child mortality rate and households with a monthly income of less than USD 100 $\left(r=0.868^{* *}\right.$ and $\left.p=0.000\right)$, the number of people without health insurance $\left(r=0.803^{* *}\right.$ and $\left.p=0.000\right)$, and the size of the native indigenous population $\left(r=0.763^{* *}\right.$ and $p=0.001$ ). There is also a significant positive correlation between the average child mortality rate and the number of illiterate people $\left(r=0.746^{* *}\right.$ and $\left.p=0.001\right)$, the number of households without a sewage system $(r=0.734 * *$ and $p=0.002)$, the size of the rural population $(r=0.729 * *$ and $p=0.002)$, the number of people per household $\left(r=0.712^{* *}\right.$ and $\left.p=0.003\right)$, and the number of people younger than 5 years old $(r=0.690 * *$ and $p=0.004)$. There is no correlation between the number of households without access to a water source $(r=0.226$ and $p=4.18)$ and the average child mortality rate in contrast to expectations. The results of the correlation analysis are presented in Table 3.

\subsection{Regression Analysis}

The regression analysis considers the average child mortality rate at the municipal level between 2012 and 2016 as the dependent variable, and it takes all the socioeconomic variables as independent variables. Those that best explain the distribution were households with a monthly income of less than USD 100, the number of people older than 65, and the number of people younger than 5 years old.

Table 4 presents a summary of the model provided by SPSS 25. Table 4a lists the variables selected for the final model. Table $4 \mathrm{~b}$ includes the value of the correlation coefficient, or $\mathrm{R}$, and the derived $\mathrm{R}^{2}$ for the model considering only the variables listed in Table $4 \mathrm{a}$. Table $4 \mathrm{c}$ lists the excluded variables due to their degree of collinearity. According to Table $4 \mathrm{~b}$ the average child mortality rate against the socioeconomic variables selected, $\mathrm{R}$ has a value of 0.951 , and $\mathrm{R}^{2}$ is 0.904 . This shows that belonging to a household with a monthly income of less than USD 100, with no members older than 65 , but several children younger than 5 years old, accounts for $90.4 \%$ of the child mortality rate at the municipal level for the period 2012-2016 in La Guajira, Colombia. 


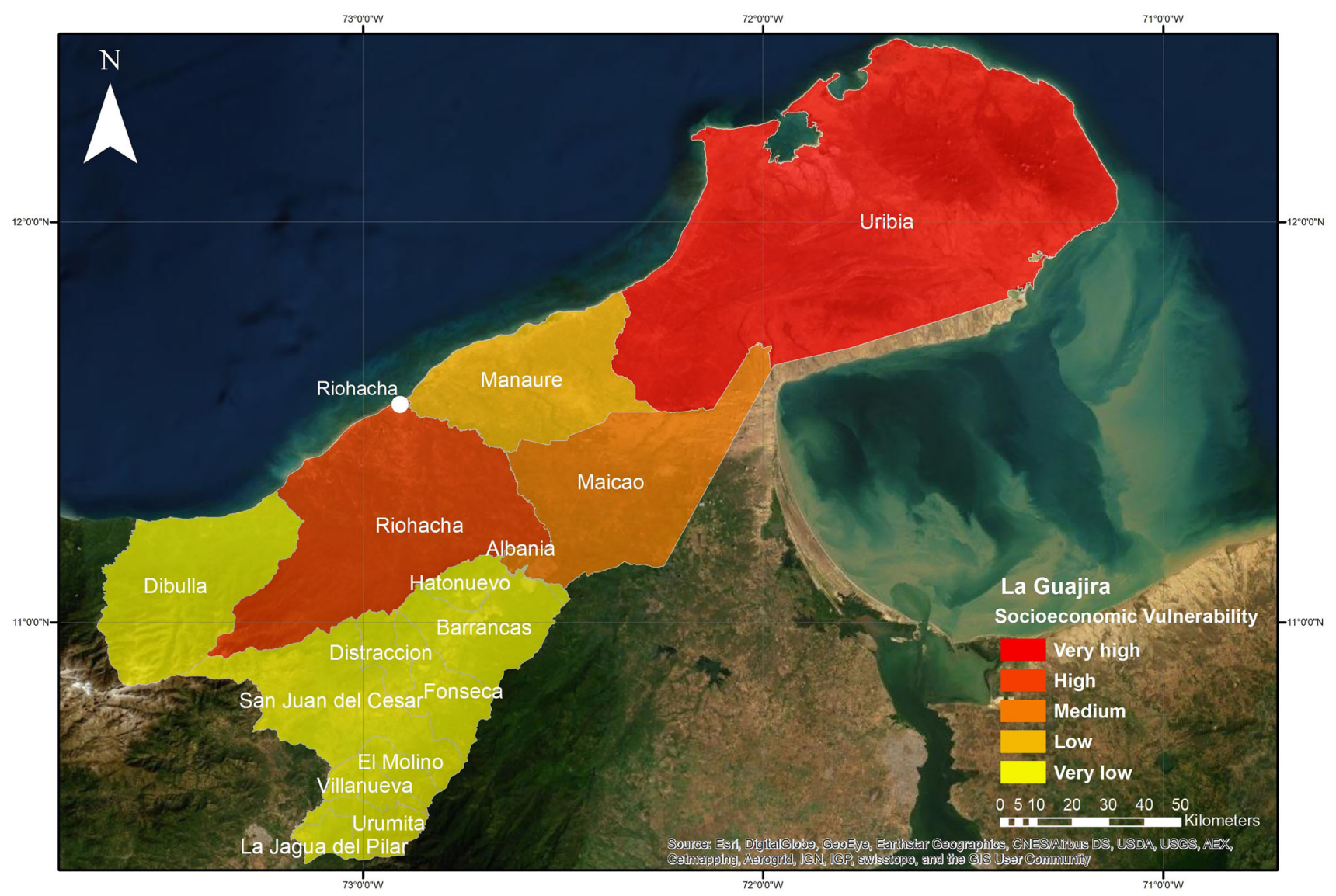

Fig. 5 Socioeconomic vulnerability in La Guajira, Colombia

\section{Discussion}

The very high, high, medium, and low levels of socioeconomic vulnerability correspond with the driest natural subregions of the department - the high and middle Guajira, while the lowest level of socioeconomic vulnerability is identified in the low Guajira, the natural subregion with more agriculture potential and water availability. Based on this finding we can assume that the most affected by the drought due to their location are the Wауии indigenous community. Besides the drought, a factor that could have contributed to reducing the income of the Wayиu families, especially in the municipalities of Uribia and Maicao, is the intermittent closing of the borders with Venezuela due to the political turmoil and the shortage of basic products in Venezuela, and the lack of connection of La Guajira's economy with the rest of Colombia (Contreras et al. 2016). Uribia and Maicao are located on the border with Venezuela, their inhabitants have coped with drought with seasonal migration and smuggling. Nevertheless, the closing of the border by the Venezuelan army did not stop the migration from Venezuela to Colombia. The Wауии in Venezuela flee hunger, hyperinflation, and political repression in Venezuela to claim their rights to land and settle in Colombia. These rights are justified by the presence of the remains of their ancestors resting in the Wayuu cemeteries in La Guajira. The arrival of the Venezuelan Wауии has generated conflict with the Colombian Wayиu clans already living in those territories, not only due to some cultural differences, even though they are also Wауии, but also because of the additional pressure that their presence represents on scarce resources such as land, water, and food. These facts have generated xenophobia, and the Venezuelan Wауии are, for example, accused of bringing illness, which could be the result of the poor condition of the healthcare infrastructure in Venezuela (Casey and Iguarán 2019). The low-skill jobs that in the past used to be a source of income for the Colombian Wауии during drought are now sometimes occupied by migrants from Venezuela, and the humanitarian aid to respond to the hunger among the Wayиu population had to be extended to include the migrant population of Venezuela (Contreras 2019). This population usually arrives in exceptionally poor health conditions due to hunger in Venezuela and the long walking journey to reach the Colombian border, which involves risking their lives when they cannot go through legal immigration control due to the lack of passports. 


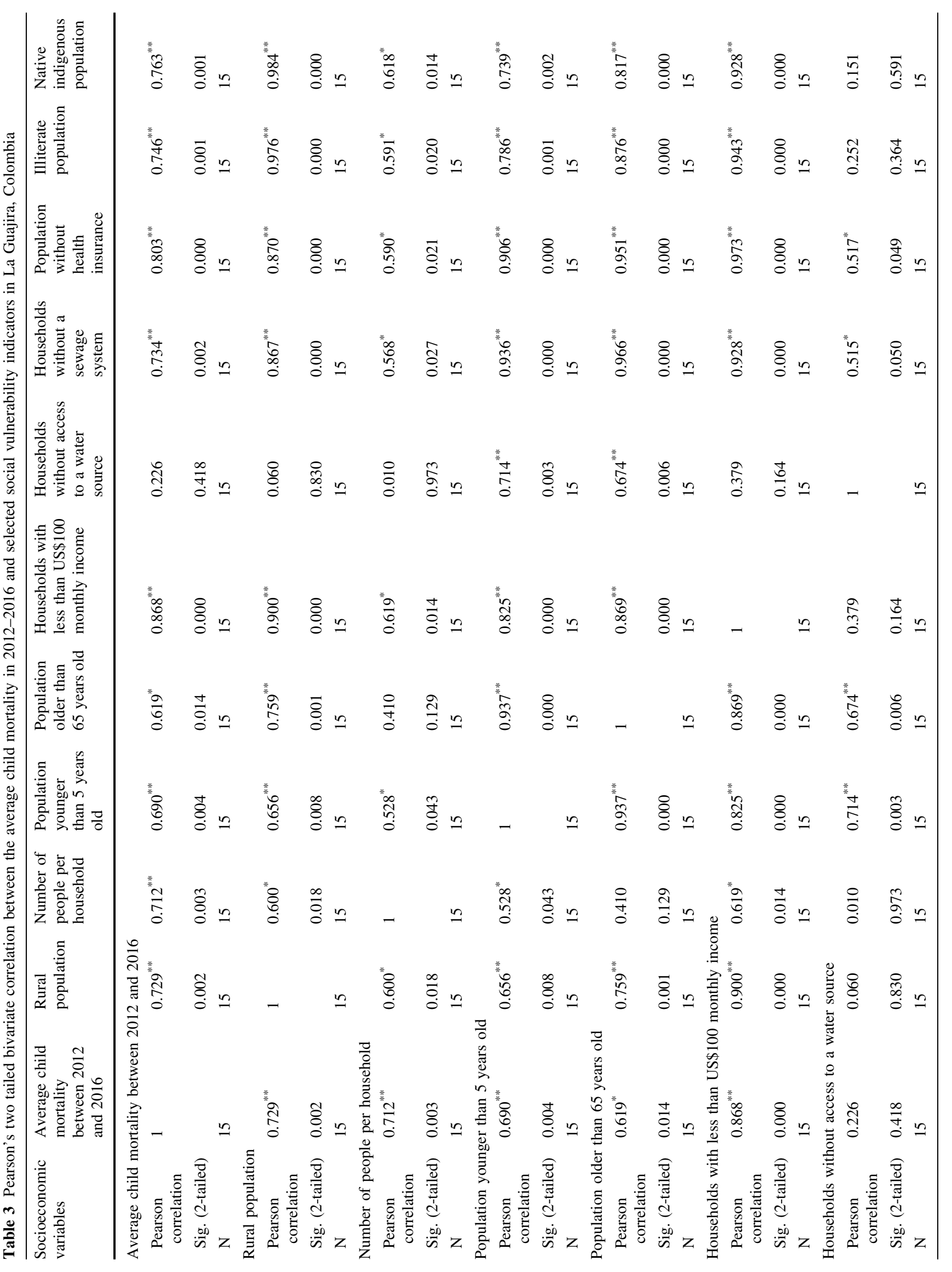




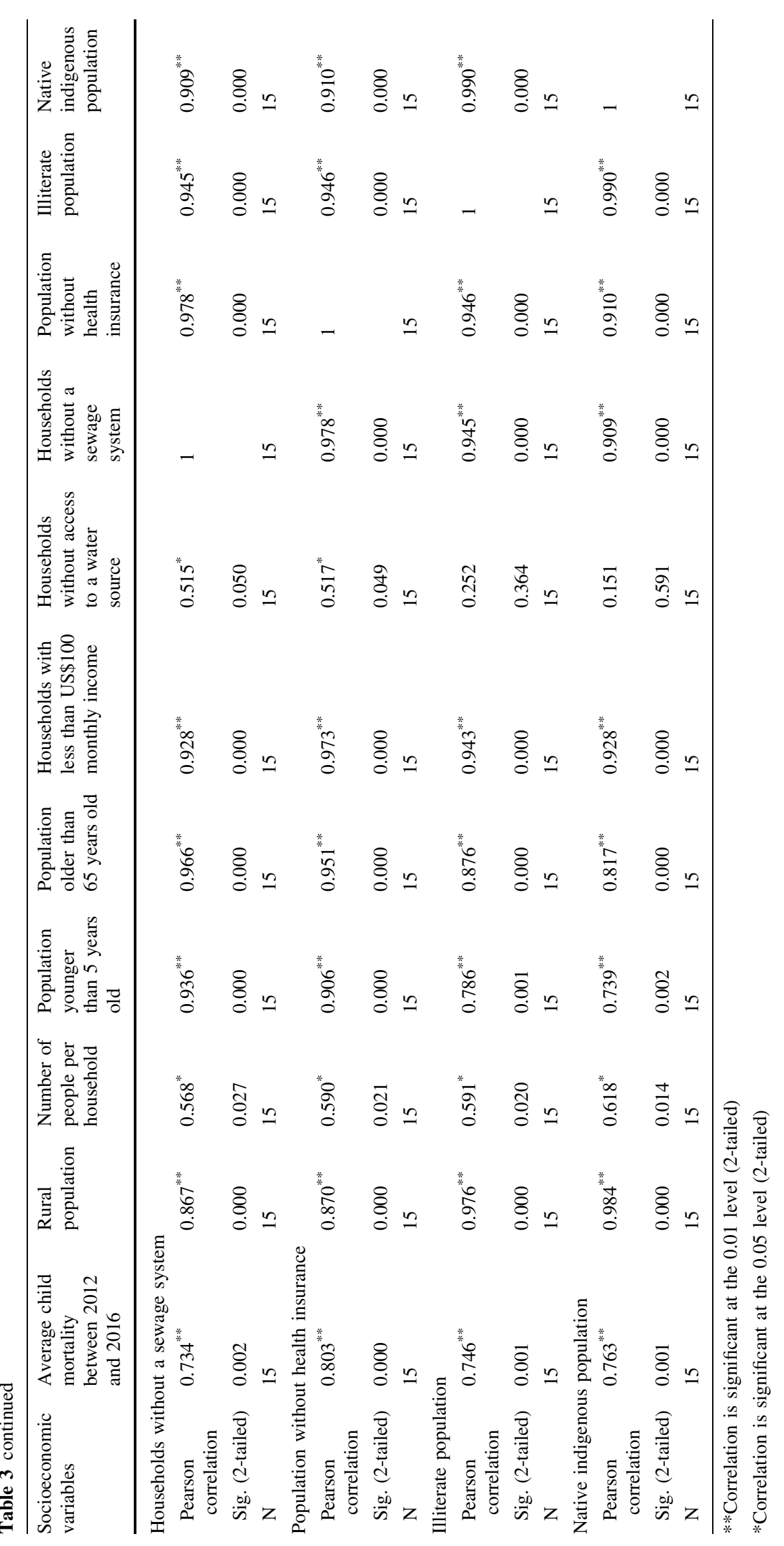


Table 4 Results from the stepwise regression analysis between average child mortality from 2012 to 2016 and selected socioeconomic indicators in La Guajira, Colombia

\begin{tabular}{|c|c|}
\hline Model & Variables Entered \\
\hline \multicolumn{2}{|c|}{ (a) Variables selected } \\
\hline 1 & $\begin{array}{l}\text { Households with less than US\$100 } \\
\text { monthly income }\end{array}$ \\
\hline 2 & Population older than 65 years old \\
\hline 3 & Population younger than 5 years old \\
\hline
\end{tabular}

Variables $\quad$ Method
removed

removed

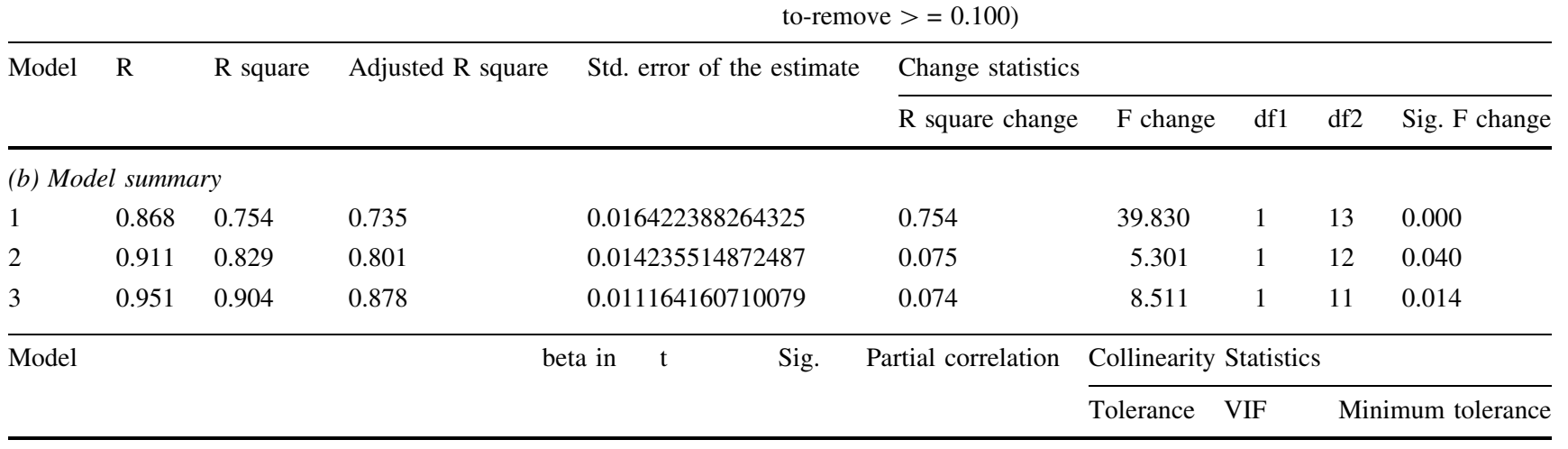

\section{(c) Excluded variables}

Model 1

$\begin{array}{lrrrrrrr}\text { Number of people per household } & 0.282 & 1.733 & 0.109 & 0.447 & 0.617 & 1.620 & 0.617 \\ \text { Population younger than 5 years old } & -0.084 & -0.334 & 0.744 & -0.096 & 0.319 & 3.133 & 0.319 \\ \text { Population older than 65 years old } & -0.555 & -2.302 & 0.040 & -0.554 & 0.245 & 4.082 & 0.245 \\ \text { Households without access to a water source } & -0.121 & -0.799 & 0.440 & -0.225 & 0.856 & 1.168 & 0.856 \\ \text { Households without a sewage system } & -0.523 & -1.476 & 0.166 & -0.392 & 0.138 & 7.244 & 0.138 \\ \text { Population without health insurance } & -0.782 & -1.360 & 0.199 & -0.365 & 0.054 & 18.590 & 0.054 \\ \text { Illiterate population } & -0.651 & -1.690 & 0.117 & -0.438 & 0.112 & 8.963 & 0.112 \\ \text { Native indigenous population } & -0.306 & -0.818 & 0.430 & -0.230 & 0.139 & 7.218 & 0.139 \\ \text { Model 2 } & & & & & & & \\ \text { Number of people per household } & 0.188 & 1.191 & 0.259 & 0.338 & 0.551 & 1.815 & 0.162 \\ \text { Population younger than 5 years old } & 0.783 & 2.917 & 0.014 & 0.660 & 0.122 & 8.225 & 0.093 \\ \text { Households without access to a water source } & 0.237 & 1.238 & 0.242 & 0.350 & 0.371 & 2.693 & 0.106 \\ \text { Households without a sewage system } & 0.454 & 0.696 & 0.501 & 0.205 & 0.035 & 28.568 & 0.035 \\ \text { Population without health insurance } & 2.022 & 1.640 & 0.129 & 0.443 & 0.008 & 121.902 & 0.008 \\ \text { Illiterate population } & -0.417 & -1.105 & 0.293 & -0.316 & 0.098 & 10.178 & 0.098 \\ \text { Native indigenous population } & -0.266 & -0.818 & 0.431 & -0.239 & 0.138 & 7.240 & 0.102 \\ \text { Model 3 } & & & & & & & \\ \text { Number of people per household } & 0.001 & 0.005 & 0.996 & 0.002 & 0.408 & 2.454 & 0.062 \\ \text { Households without access to a water source } & 0.053 & 0.301 & 0.770 & 0.095 & 0.302 & 3.312 & 0.080 \\ \text { Households without a sewage system } & -0.191 & -0.332 & 0.746 & -0.105 & 0.029 & 34.649 & 0.029 \\ \text { Population without healthinsurance } & 1.282 & 1.218 & 0.251 & 0.359 & 0.008 & 132.180 & 0.008 \\ \text { Illiterate population } & -0.090 & -0.265 & 0.796 & -0.084 & 0.083 & 12.019 & 0.070 \\ \text { Native indigenous population } & -0.070 & -0.257 & 0.802 & -0.081 & 0.128 & 7.828 & 0.087\end{array}$

Dependent variable: Average child mortality between 2012 and 2016

1. Predictors: (Constant), Households with less than US\$100 monthly income

2. Predictors: (Constant), Households with less than US $\$ 100$ monthly income, Population older than 65 years old

3. Predictors: (Constant), Households with less than US $\$ 100$ monthly income, Population older than 65 years old, Population younger than 5 years old 
Illiteracy in La Guajira must be understood as the inability to read or write Spanish. A significant proportion of the Wayuu population only speaks Wayuunaiki, the official Wayuu language (Hostein 2012; CC 2015), and they are not able to communicate in Spanish. This is confirmed by the strong correlation between the size of the illiterate population and the native indigenous population $(r=0.990 * *$ and $p=0.000)$. This explains the strong correlation between the average child mortality rate and illiteracy: when Waуuи mothers arrive at healthcare facilities with highly undernourished children, they cannot understand the medical diagnosis and treatment recommendations and are unable to follow the proper treatment (Pirry 2014; CC 2015).

The strong correlation between the size of the rural population and child mortality can be explained by all the challenges that communities in rural areas, and mainly indigenous communities $\left(r=0.990^{* *}\right.$ and $\left.p=0.000\right)$ in Uribia, Manaure, Maicao, and Riohacha, have to face, such as a monthly income of less than USD $100(r=0.984 * *$ and $p=0.000)$, the lack of a sewage system $(r=0.867 * *$ and $p=0.000)$, and a lack of health insurance $(r=0.870 * *$ and $p=0.000$. Another factor is the lack of birth control among the Wayuu communities, which explains the strong correlation between the size of the rural population and the number of people per household in rural areas $(r=0.600 * *$ and $p=0.018$ ), as well as the number of people younger than 5 years old $(r=0.600 * *$ and $p=0.018)$. There is also a highly significant correlation between the size of the rural population and the number of people older than 65 years old $(r=0.750 * *$ and $p=0.001)$.

According to Raleigh and Urdal (2007), in arid environments water scarcity is the consequence of the unfair distribution of water resources. The results of the correlation analysis dismiss lack of access to a water source as the primary reason for child mortality $(r=0.226$ and $p=0.418$ ). This lack of correlation can be explained by the fact that, although there is no infrastructure for water supply in Uribia and Maicao, the municipalities with the highest rates of child mortality, the government and the private sector supply drinking water to these municipalities using water tanker trucks.

The explanatory power of the average child mortality between 2012 and 2016 due to the number of households with less than USD 100 monthly income is justified because of the reduction in the income of the families due to the political and economic problems of Venezuela and the lack of connection of the La Guajira with the rest of Colombia. The negative explanatory power of the number of people older than 65 years old for child mortality can be understood as the presence in the household of a person with assets such as animals and savings accumulated through his/her life that can be used for consumption or to purchase food during drought, which reduces the probability of child mortality in that specific household.

\section{Conclusion}

Taking into account the correlation analysis, it can be concluded that the drivers of child mortality during the 2012-2016 period were the high socioeconomic vulnerability conditions. The level of socioeconomic vulnerability of the inhabitants in La Guajira is in turn determined by the natural subregion where they live. The agriculture potential and the availability of water in the low Guajira allow to have crops and raise animals, hence to have an income greater than USD 100 to cover basic needs and even make profit, which in turn contributes to having the lowest child mortality rates in the department. Unfortunately, Wayuu indigenous community inhabits the driest subnatural regions-high and middle La Guajira, which make them more vulnerable.

The hypothesis that the high child mortality rate between 2012 and 2016 in La Guajira was triggered by the lack of access to water sources due to the drought caused by the El Niño event is rejected in the sense that variables such as households with a monthly income of less than USD 100, the number of people older than 65 years old, and the number of children younger than 5 years old were determined by the stepwise regression analysis as the explanatory variables of this phenomenon.

If the Wayuu indigenous community had an income to cover their basic needs; health insurance adapted to their traditions, with medical doctors and nurses able to speak their language and involving traditional Wауии healers in their prevention campaigns; and adequate interdependent infrastructure such as paved roads, water and sewage systems, electricity, and communications and healthcare facilities in the rural areas, they could have faced the drought without the observed increase in child mortality rates. Rather than water scarcity, the real problem could be the lack of basic sanitation due to the lack of sewage systems, which results in the contamination of the water stored by communities or taken from the jagüeyes (openair water reservoirs); this mainly affects children (Avilés 2019). This could be the reason for the acute diarrheal disease that is usually linked to undernourishment in $\mathrm{La}$ Guajira.

The existence of an effective EWS in La Guajira could have prevented or at least reduced the level of child mortality among the Wayuu population, allowing the government to design a plan based on a spatial planning support system (SPSS) to distribute food supplements and drinking water and monitor health condition among children. 


\section{Recommendations}

It is essential to reduce the socioeconomic vulnerability in La Guajira, and mainly in the municipalities located in the high and middle Guajira. This would allow the communities to be prepared for the challenges imposed by climate change and would increase their resilience through adaptation measures rather than coping capacities.

It is vital to train the inhabitants of La Guajira on the importance of techniques to diversify income risk or to earn off-farm income, for instance with ecotourism (Contreras et al. 2016) and ethno-tourism. It is important to implement adaptation strategies based on ecosystem services as an alternative source of income involving tourist guides, fishermen, the Wауии indigenous community, the National Natural Parks of Colombia, and the Ministry of Business, Industry, and Tourism (Contreras 2019). Some such activities already exist, such as birdwatching in the township of Camarones and windsurfing in El Cabo de la Vela. It is necessary to increase the coverage of health insurance by providing more facilities, increasing the capacity of the existing ones, and/or strengthening the already existing mobile health brigades. It is essential to improve basic sanitation in the Wayuu settlements. Moreover, new methods should be considered to collect water such as surface runoff rainwater harvesting and fog water harvesting through nets (Nash 1992; Abdul-Wahab and Lea 2008; Fessehaye et al. 2014; LeBoeuf and de la Jara 2014; Dodson and Bargach 2015; Harb et al. 2016).

According to Desalegn et al. (2006), there should be a network of EWS for drought so that farmers can be prepared and reduce the next drought's impact on them and their region. It is necessary to enhance the existing EWS in La Guajira developed by the UNGRD and FAO to be prepared for the next drought.

Another recommendation is to resort to a government drought relief program, which would act as a safety net to obtain financial services, such as access to microinsurance (Hallegatte 2016), supplemental feed, or water (Nagler et al. 2007; Coppock 2011; Wilmer 2016; Shrum et al. 2018), or programs such as "cash for work" pioneered by the FAO.

Acknowledgements This article was written within the framework of the Resilience Academy (RA 2013-2014) "Exploring Livelihood Resilience" and the project "Social Vulnerability to Natural Hazards and dependence to Urban Critical Infrastructure: Spatial Model for Drinking Water and Healthcare Systems" sponsored by CONICYT/ FONDAP/15,110,017, Research Center for Integrated Disaster Risk Management (CIGIDEN). We thank the Munich Re Foundation for the sponsorship of the RA and Capstone Conference (2017), and the United Nations University - Institute for Environment and Human Security (UNU-EHS) and the International Centre for Climate Change and Development (ICCCAD) for co-organizing this event. We are grateful with Dr. Ryan Alaniz from the California Polytechnic
State University, San Luis Obispo, and Mr. Roger-Mark de Souza from Amnesty International USA for hosting the preliminary presentations of this research. We would like to acknowledge Ms. Janne Christ from Caritas Switzerland, Mr. Ascanio Vega and Mr. Julio Salas from the Diocese of Riohacha for their support to the present research. We would like to thank Dr. David Milledge and Mr. Bryan Chalarca Echeverry for their support with the statistical analysis and data recovery, respectively. Finally, we would like to acknowledge the anonymous reviewers for their significant contribution to the improvement of the final version of this paper.

Open Access This article is licensed under a Creative Commons Attribution 4.0 International License, which permits use, sharing, adaptation, distribution and reproduction in any medium or format, as long as you give appropriate credit to the original author(s) and the source, provide a link to the Creative Commons licence, and indicate if changes were made. The images or other third party material in this article are included in the article's Creative Commons licence, unless indicated otherwise in a credit line to the material. If material is not included in the article's Creative Commons licence and your intended use is not permitted by statutory regulation or exceeds the permitted use, you will need to obtain permission directly from the copyright holder. To view a copy of this licence, visit http://creativecommons. org/licenses/by/4.0/.

\section{References}

Abdul-Wahab, S.A., and V. Lea. 2008. Reviewing fog water collection worldwide and in Oman. International Journal of Environmental Studies 65(3): 487-500.

Allouche, J. 2011. The sustainability and resilience of global water and food systems: Political analysis of the interplay between security, resource scarcity, political systems and global trade. Food Policy 36: S3-S8.

Avilés, A. 2019. The Wayúu tragedy: Death, water and the imperatives of global capitalism. Third World Quarterly 40(9): $1750-1766$.

Bonet-Morón, J., and L.W. Hahn-De-Castro. 2017. Child mortality and malnutrition in La Guajira (La mortalidad y desnutrición infantil en La Guajira). In Working Papers on Regional Economy (Documentos de Trabajo sobre Economia Regional). Cartagena, Colombia Banco de La Republica. http://www. banrep.gov.co/docum/Lectura_finanzas/pdf/dtser_255.pdf. Accessed 6 Feb 2020.

Bortolini, G.A., M.B. Gubert, and L.M. Santos. 2012. Food consumption Brazilian children by 6 to 59 months of age (Consumo alimentar entre crianças brasileiras com idade de 6 a 59 meses). Cad Saude Publica 28(9): 1759-1771 (in Portuguese).

Casey, N., and M. Iguarán. 2019. The collapse of Venezuela threatens the existence of the ancient Wayuu people (El colapso de Venezuela amenaza la existencia del pueblo ancestral wayuu). The New York Times ES, 30 July 2019, America Latina. https:// www.nytimes.com/es/2019/07/30/wayuu-venezuela-crisis/. Accessed 27 Jan 2020 (in Spanish).

Castro-Aniyar, D. 2016. The goat and the ram in the Wayuu culture. Transhumance, economy and customary law (El Chivo y el Ovejo en la Cultura Wayúu Trashumancia, economía y derecho consuetudinario). Manta, Ecuador: Mar Abierto. https://issuu. com/marabiertouleam/docs/el_chivo_y_el_ovejo_final_digital. Accessed 3 Feb 2020 (in Spanish).

CC (Capital Channel/Canal Capital). 2015. Wayuu genocide (Genocidio Wayúu). https://www.youtube.com/watch?v=QILpfL3Gvs\&t=610s. Accessed 27 Jan 2020 (in Spanish). 
CCG (Cámara de Comercio de La Guajira/Chamber of Commerce La Guajira). 2017. Socioeconomic report of La Guajira. Study on the territorial economic performance of La Guajira (Informe socioeconomico de La Guajira. Estudio sobre el desempeño economico territorial de La Guajira). http://www.camaraguajira. org/publicaciones/informes/estudio-economico-de-la-guajira2017.pdf. Accessed 27 Jan 2020 (in Spanish).

Coleman-Jensen, A., M. Nord, and A. Singh. 2013. Household food security in the United States in 2012. Washington, DC: United States Department of Agriculture (USDA).

Contreras, D. 2019. The integrated spatial pattern of child mortality during the 2012-2016 drought in La Guajira, Colombia. Sustainability 11(24): Article 7190.

Contreras, D., S. Bhamidipati, and S. Contreras. 2016. The fight of the Wayuu ethnic community against the drought in La Guajira, Colombia. The 6th International Disaster and Risk Conference IDRC Davos 2016, Davos, Switzerland.

Cook, J.T. 2002. Clinical implications of household food security: Definitions, monitoring, and policy. Nutrition in Clinical Care 5(4): 152-167.

Cook, J.T., D.A. Frank, C. Berkowitz, M.M. Black, P.H. Casey, D.B. Cutts, A.F. Meyers, N. Zaldivar, et al. 2004. Food insecurity is associated with adverse health outcomes among human infants and toddlers. Journal of Nutrition 134(6): 1432-1438.

Coppock, D.L. 2011. Ranching and multiyear droughts in Utah: Production impacts, risk perceptions, and changes in preparedness. Rangeland Ecology \& Management 64(6): 607-618.

Correa, V. 2015. 17 million liters per day consumes Cerrejon everyday but it is people who have save water? (17 millones de litros de agua consume Cerrejón diariamente iy es el pueblo el que tiene que ahorrar?). https://www.youtube.com/watch? $\mathrm{v}=$ KO1LWqK52j8. Accesed 28 Jan 2020 (in Spanish).

DANE (Departamento Administrativstivo Nacional de Estadística/ National Department of Statistics of Colombia). 2017. Estimations of the child mortality rate at national, regional and local level for the period 2005-2016 (Estimaciones Tasa de mortalidad infantil nacional, departamental y municipal, período 2005-2016). Bogota, Colombia: DANE (in Spanish).

de Sousa, L.R.M., A. Saint-Ville, L. Samayoa-Figueroa, and H. Melgar-Quinonez. 2019. Changes in food security in Latin America from 2014 to 2017. Food Security 11(3): 503-513.

Delbiso, T.D., C. Altare, J.M. Rodriguez-Llanes, S. Doocy, and D. Guha-Sapir. 2017. Drought and child mortality: A meta-analysis of small-scale surveys from Ethiopia. Scientific Reports 7(1): Article 2212.

Desalegn, C.E., M.S. Babel, A.D. Gupta, B.A. Seleshi, and D. Merrey. 2006. Farmers' perception of water management under drought conditions in the upper Awash Basin, Ethiopia. International Journal of Water Resources Development 22(4): 589-602.

Diaz, D., and J. Rubiano. 2018. Climate change impact assessment and preliminary proposal for agricultural systems against climate change adaptation in La Guajira-Colombia (Evaluación de Impactos del Cambio Climático y propuesta preliminar para sistemas agropecuarios frente a la adaptación al cambio climático en la Guajira-Colombia). Technical report. Cali, Colombia: Semillas de Agua (in Spanish).

Dodson, L.L., and J. Bargach. 2015. Harvesting fresh water from fog in rural Morocco-Research and impact Dar Si Hmad's fogwater project in Aït Baamrane. Procedia Engineering 107: 186-193.

Ebi, K.L., and K. Bowen. 2016. Extreme events as sources of health vulnerability: Drought as an example. Weather and Climate Extremes 11: 95-102.

Espinosa-Cristia, J.F., J. Feregrino, and P. Isla. 2019. Emerging, and old, dilemmas for food security in Latin America. Journal of Public Affairs 19(3): Article e1999.
Estrela, T., and E. Vargas. 2012. Drought management plans in the European Union: The case of Spain. Water Resources Management 26(6): 1537-1553.

FAO (Food and Agriculture Organization). 2012. Latin American and Caribbean food security scale (Escala Latinoamericana y Caribeña de Seguridad Alimentaria (ELCSA): Manual de uso y aplicación). Santiago, Chile: Organizacion de las Naciones Unidas para la Agricultura y la Alimentacion (FAO), Oficina Regional para America Latina (in Spanish).

FAO (Food and Agriculture Organization). 2013. Climate-smart agriculture. Rome: FAO.

FAO, IFAD, and WFP (Food and Agriculture Organization, International Fund for Agricultural Development, and World Food Programme). 2015. The state of food insecurity in the world 2015. Meeting the 2015 international hunger targets: Taking stock of uneven progress. Rome: FAO.

FAO and PAHO (Food and Agriculture Organization and the Pan American Health Organization). 2017. Panorama of food and nutrition security in Latin America and the Caribbean. Santiago de Chile: FAO and PAHO.

FAO/FSNAU (Food and Agriculture Organization/Food Security and Nutrition Analysis Unit). 2006. Integrated food security and humanitarian phase classification: Technical manual version 1 . Evidence and standards for better food security decisions. Nairobi: FAO/FSNAU.

Fessehaye, M., S.A. Abdul-Wahab, M.J. Savage, T. Kohler, T. Gherezghiher, and H. Hurni. 2014. Fog-water collection for community use. Renewable \& Sustainable Energy Reviews 29: $52-62$.

Fischer, N.C., T. Shamah-Levy, V. Mundo-Rosas, I. Méndez-GómezHumarán, and R. Pérez-Escamilla. 2014. Household food insecurity is associated with anemia in adult Mexican women of reproductive age. The Journal of Nutrition 144(12): 2066-2072.

Guerra, W. 2016. The humanitarian drama of the Wayuu childhood (El drama humanitario de la niñez. Wayuu). Presentation at the Bartolomé Calvo Library in Cartagena, March 2016.

Guillén, G. 2016. "The river that was stolen", the documentary that seeks to explain the death of the Wayuu ('El río que se robaron', el documental que busca explicar la muerte de los Wayúu). Noticias RCN (in Spanish).

Hadley, C., A. Tegegn, F. Tessema, J.A. Cowan, M. Asefa, and S. Galea. 2008. Food insecurity, stressful life events and symptoms of anxiety and depression in east Africa: Evidence from the Gilgel Gibe growth and development study. Journal of Epidemiology and Community Health 62(11): 980-986.

Hallegatte, S., B. Mook, L. Bonzanigo, M. Fay, T. Kane, U. Narloch, J. Rozenberg, D. Treguer, and A. Vogt-Schilb. 2016. Shock waves, managing the impacts of climate change on poverty. Washington, DC: World Bank Group.

Harb, O.M., M.Sh. Salem, G.H.A. El-Hay, and Kh.M. Makled. 2016. Fog water harvesting providing stability for small Bedwe communities lives in North cost of Egypt. Annals of Agricultural Sciences 61(1): 105-110.

Hostein, N. 2012. The Wayuu people of the Colombian-Venezuelan Guajira: An overview of their culture (El pueblo wayuu de la Guajira colombo-venezolana: un panorama de su cultura). Cuadernos de Antropología 20(1). https://revistas.ucr.ac.cr/ index.php/antropologia/article/view/2006/1973. Accessed 27 Jan 2020 (in Spanish).

IDEAM, PNUD, MADS, DNP, and CANCILLERIA. 2017. Third national communication of Colombia to the United Nations Framework Convention on Climate Change (UNFCCC) (Tercera Comunicacion Nacional de Colombia a La Convención Marco de las Naciones Unidas sobre el Cambio Climático 
$(C M N U C C))$. Bogota D.C., Colombia: IDEAM, ${ }^{1}$ PNUD ${ }^{2}$ MADS,${ }^{3}$ DNP,${ }^{4}$ CANCILLERIA, ${ }^{5}$ and FMAM $^{6}$ (in Spanish).

Jaeger, W.K., A.J. Plantinga, H. Chang, K. Dello, G. Grant, D. Hulse, J.J. McDonnell, S. Lancaster et al. 2013. Toward a formal definition of water scarcity in natural-human systems. Water Resources Research 49(7): 4506-4517.

Jülich, S. 2011. Drought triggered temporary migration in an East Indian village. International Migration 49(s1): e189-e199.

Kahil, M.T., A. Dinar, and J. Albiac. 2016. Cooperative water management and ecosystem protection under scarcity and drought in arid and semiarid regions. Water Resources and Economics 13: 60-74.

Keller, M., and M. Künzler. 2014. Participatory Assessment of Climate and Disaster Risks (PACDR). Berna, Switzerland: Brot für alle - Pain pour le prochain.

LeBoeuf, R., and E. de la Jara. 2014. Quantitative goals for largescale fog collection projects as a sustainable freshwater resource in northern Chile. Water International 39(4): 431-450.

Mining Technology. 2013. The 10 biggest coal mines in the world. Mining Technology, 20 October 2013. https://www.miningtechnology.com/features/feature-the-10-biggest-coal-mines-inthe-world/. Accessed 5 Oct 2019.

Mishra, A.K., and V.P. Singh. 2010. A review of drought concepts. Journal of Hydrology 391: 202-216.

Nagler, A., S. Mooney, M. Frasier, C.T. Bastian, S.I. Paisley, W. Umberger, J.P. Hewlett, M.A. Smith, and P. Ponnameneni. 2007. Multiple impacts - multiple strategies: How Wyoming Cattle producers are surviving in prolonged drought. Laramie, WY: University of Wyoming. http://wyomingextension.org/agpubs/ pubs/B1178.pdf. Accessed 28 Nov 2019.

Nash, N. 1992. Chilean engineers find water for desert by harvesting fog in nets. The New York Times. https://www.nytimes.com/ 1992/07/14/science/chilean-engineers-find-water-for-desert-byharvesting-fog-in-nets.html. Accessed 27 January 2020.

Nhamo, L., T. Mabhaudhi, and A.T. Modi. 2019. Preparedness or repeated short-term relief aid? Building drought resilience through early warning in southern Africa. Water SA 45(1): $75-85$.

Pedro-Monzonís, M., A. Solera, J. Ferrer, T. Estrela, and J. ParedesArquiola. 2015. A review of water scarcity and drought indexes in water resources planning and management. Journal of Hydrology 527: 482-493.

Pérez-Escamilla, R., and A.M. Segall-Corrêa. 2008. Food insecurity measurement and indicators. Revista de Nutrição 21: 15s-26s.

Pérez-Escamilla, R., M. Dessalines, M. Finnigan, H. Pachón, A. Hromi-Fiedler, and N. Gupta. 2009. Household food insecurity is associated with childhood malaria in rural Haiti. The Journal of Nutrition 139(11): 2132-2138.

\footnotetext{
${ }^{1}$ IDEAM (Instituto de Hidrologia, Meteorología y Estudios Ambientales/Institute of Hydrology, Meteorology and Environmental Studies) http://www.ideam.gov.co/faces/portal/default.jsp.

2 PNUD (Programa de las Naciones Unidas para el Desarrollo/United Nations Development Programme - UNDP) https://www.undp.org/.

${ }^{3}$ MADS (Ministerio de Ambiente y Desarrollo Sostenible/Ministry of Environment and Sustainable Development) https://www.minam biente.gov.co/.

${ }^{4}$ DNP (Departamento Nacional de Planeación/National Planning Department) https://www.dnp.gov.co/DNPN/Paginas/default.aspx.

5 CANCILLERIA (Ministerio de Relaciones Exteriores/Ministry of Foreign Affiars) https://www.cancilleria.gov.co/.

${ }^{6}$ FMAM (El Fondo para el Medio Ambiente Mundial/The Fund for Global Environment Facility - GEF) http://www.fao.org/gef/es/.
}

Pérez-Escamilla, R., J.E. Obbagy, J.M. Altman, E.V. Essery, M.M. McGrane, Y.P. Wong, J.M. Spahn, and C.L. Williams. 2012. Dietary energy density and body weight in adults and children: A systematic review. Journal of the Academy of Nutrition and Dietetics 112(5): 671-684.

Pirry. 2014. Famine in La Guajira (Hambruna en La Guajira). https:// www.youtube.com/watch?v=L2QJ7hjWZOM. Accessed 27 Jan 2020.

Poblacion, A.P., J.T. Cook, L. Marin-Leon, A.M. Segall-Correo, J.A.C. Silveira, T. Konstantyner, and J.A.A.C. Taddei. 2016. Food insecurity and the negative impact on Brazilian children's health-Why does food security matter for our future prosperity? Brazilian national survey (PNDS 2006/07). Food and Nutrition Bulletin 37(4): 585-598.

Poblacion, A.P., L. Marın-Leon, A.M. Segall-Correa, J.A. Silveira, and J.A. Taddei. 2014. Food insecurity in Brazilian families with children under five years of age (Insegurança alimentar em domicílios brasileiros com crianças menores de cinco anos). Cad Saude Publica 30(5): 1067-1078 (in Portuguese).

Raleigh, C., and H. Urdal. 2007. Climate change, environmental degradation and armed conflict. Political Geography 26(6): 674-694.

Reuveny, R. 2007. Climate change-induced migration and violent conflict. Political Geography 26(6): 656-673.

Ribera, L.A. 2012. Climate change, agriculture and food security in Latin America. American Journal of Agricultural Economics 94(5): 1236-1237.

Rodriguez, D.I., G. Anriquez, and J.L. Riveros. 2016. Food security and livestock: The case of Latin America and the Caribbean. Ciencia E Investigacion Agraria 43(1): 1-15.

Schnegg, M., and M. Bollig. 2016. Institutions put to the test: Community-based water management in Namibia during a drought. Journal of Arid Environments 124: 62-71.

Shrum, T.R., W.R. Travis, T.M. Williams, and E. Lih. 2018. Managing climate risks on the ranch with limited drought information. Climate Risk Management 20: 11-26.

Silva, S. 2016. The stream that crossed the Cerrejón (El arroyo que se le atravesó al Cerrejón). El Espectador, 7 March 2016, Medio Ambiente. http://www.elespectador.com/noticias/medioambiente/el-arroyo-se-le-atraveso-al-cerrejon-articulo-548145. Accessed 27 Jan 2020 (in Spanish).

Smith, M.D., W. Kassa, and P. Winters. 2017. Assessing food insecurity in Latin America and the Caribbean using FAO's Food Insecurity Experience Scale. Food Policy 71: 48-61.

Sperandio, N., D.D. Morais, and S.E. Priore. 2018. Perception scales of validated food insecurity: The experience of the countries in Latin America and the Caribbean. Ciencia \& Saude Coletiva 23(2): 449-462.

Stanke, C., M. Kerac, C. Prudhomme, J. Medlock, and V. Murray. 2013. Health effects of drought: A systematic review of the evidence. PLoS Currents 5. https://doi.org/10.1371/currents.dis. 7a2cee9e980f91ad7697b570bcc4b004.

The Guardian. 2015. Colombia's pipes to nowhere: Villagers die of thirst as corruption stalls dam project. The Guardian, 18 Jun 2015. https://www.theguardian.com/global-development/2015/ jun/18/colombia-water-drought-rancheria-corruption. Accessed 27 Jan 2020.

UNISDR (United Nations International Strategy for Disaster Reduction) and CRED (Centre for Research on the Epidemiology of Disasters). 2015. The human cost of weather-related disasters 1995-2015. https://www.unisdr.org/files/46796_cop21weatherdi sastersreport2015.pdf. Accessed 28 Nov 2019.

Weigel, M.M., R.X. Armijos, M. Racines, W. Cevallos, and N.P. Castro. 2016. Association of household food insecurity with the mental and physical health of low-income urban ecuadorian 
women with children. Journal of Environmental and Public Health. https://doi.org/10.1155/2016/5256084.

Weinreb, L., C. Wehler, J. Perloff, R. Scott, D. Hosmer, L. Sagor, and C. Gundersen. 2002. Hunger: Its impact on children's health and mental health. Pediatrics 110(4): Article e41.

Wilhite, D., and M.D. Svoboda. 2000. Drought early warning systems in the context of drought preparedness and mitigation. In Proceedings of an Expert Group Meeting held, 5-7 September, Lisbon, Portugal, Early Warning Systems for Drought
Preparedness and Drought Mangement (p. 8). Geneva: World Meteorological Organization (WMO).

Wilmer, H., E. York, W.K. Kelley, M.W. Brunson. 2016. In every rancher's mind: Effects of drought on ranch planning and practice. Rangelands 38(4): 216-221.

Working Group for Mortality Estimation in Emergencies. 2007. Wanted: Studies on mortality estimation methods for humanitarian emergencies, suggestions for future research. Emerging Themes in Epidemiology 4(1): Article 9. 